\title{
Gardening in Russia: organizational, regulatory and technological aspect
}

\author{
Vasiliy Nechaev ${ }^{1, *}$, Yana Davydova ${ }^{2}$, and Nikita Ischenko ${ }^{3}$ \\ ${ }^{1}$ FSBSI Federal scientific center of agrarian economics and social development of rural areas - All- \\ Russian Scientific-Research Institute of Economics of Agriculture, 123007, 35, Khoroshevskoe \\ shosse, Moscow, Russian Federation \\ ${ }^{2}$ Moscow State Institute of International Relations (University) of the Ministry of Foreign Affairs of \\ the Russian Federation, 119454, 76, Vernadsky av., Moscow, Russian Federation \\ ${ }^{3}$ FSBEI HE «Kuban State Agrarian University named after I.T.Trubilin», 350044, 13, Kalinina str., \\ Krasnodar, Russian Federation
}

\begin{abstract}
The subject-object area of the study is the relationship of producers of fruit and berry products in the Russian Federation, with the aim of transferring the industry to the path of sustainable economic growth. A comparative analysis of production of these products in the country for the period from 2016 to 2020 has been carried out. Importance of state support measures for development of the industry is shown. The directions of development of domestic nursery breeding on the basis of improving the regulatory framework are considered. Considering that the main area of fruit and berry crops (292 thousand hectares or $63 \%$ ) is in the households of the population, therefore, it is necessary to develop their selection and assortment not only for industrial gardening, but also for households and peasant (farm) households. The necessity of granting scientific organizations the priority right to lease agricultural land for use in the study purposes has been substantiated. Transfer of the industry to an intensive development path based on the modernization of production processes is offered. Based on the materials of technological maps of horticultural organizations of the Krasnodar Territory, a list of production costs by years and the terms of their payback when laying a superintensive garden are given, which can be successfully used in business projects of the South and North Caucasian Federal Districts.
\end{abstract}

\section{Introduction}

Provision of the country's population with fruit and berry products under international sanctions is an integral part of the implementation of the provisions of the Food Security Doctrine of the Russian Federation approved by Decree of the President of the Russian Federation No. 20 dated January 21, 2020 [1]. This problem can be solved by intensifying the industry through development of domestic nursery breeding, as well as development of innovations in production, such as covering the garden with a special net. These directions will allow, on the one hand, to reduce production costs through use of domestic varieties,

\footnotetext{
*Corresponding author: vin981@yandex.ru
} 
and on the other hand, to protect fertile orchards and nurseries from hail and other natural disasters.

In the southern regions of the country, gardens of an intensive type prevail, which, due to the hailstorm, can be safely attributed to the zone of risky gardening. So, for example, in the Crimea, according to average long-term data, 20-30 days with hail are observed per year, which in a short time can completely destroy the fruit harvest. According to the data of S.I. Nechaev and N.V. Ishchenko, annual yield losses in intensive gardens from the wind can reach $30 \%$, sunburn -20 , return frosts during the flowering period - from 30 to 70 , from hail from 50 to $100 \%$. To avoid damages from natural factors, an intensive garden must be securely protected with a hail protection system. Its service life ranges from 18 to 25 years, depending on the color and type of mesh. In addition, this system does not depend on the human factor and can be used for the entire period of planting operation. Such a hail protection system costs $750-800$ thousand rubles per 1 hectare, but at the same time it allows to save up to $25 \%$ of water with drip irrigation, and the lost profit of the organization in absence of a protective system can reach 10.6 million rubles per hectare [2]. Therefore, it is no coincidence that for the harvest of 2020, the Government of the Republic of Crimea increased the revenue side of the budget by 40 million rubles in order to protect crops from hail. "The recipients of the subsidies will be farmers who, in the current financial year, have concluded contracts for provision of services with specialized organizations for protection from hail and incurred costs," said Deputy Prime Minister A. Ryumshin. He specified that the size of the subsidy will amount to more than $80 \%$ of the costs. According to him, in the 2018 season, there were 45 days with hail, 38 days with impacts. To suppress hail, 50 operations were carried out. In 2019, there are 41 days with hail and 37 days with impacts [3]. A similar situation with hail is noted in the Krasnodar and Stavropol Territories, as well as in the Volgograd, Rostov and Saratov Regions.

Another direction of the intensification of horticulture is the transition to domestic technologies and, first of all, varieties, since the natural and climatic conditions of many Russian regions differ sharply from the weather conditions of foreign countries.

\section{Methods}

The concept of the study is based on the application of methods: analysis and generalization of provisions on the issues of regulatory, organizational and technological approaches in horticulture; foresight (with an expert assessment of individual agricultural techniques); comparative analysis (in the study of existing methodological approaches to technology assessment); computational and constructive (when calculating the payback period of investments in intensive-type gardens).

\section{Results}

According to government statistics [4], the horticulture industry in the Russian Federation shows a stable positive growth trend (Table 1). 
Table 1. Areas, gross yield and yield of fruit and berry plantations in the Russian Federation [4].

\begin{tabular}{|l|c|c|c|c|c|c|}
\hline & \multicolumn{7}{|c|}{ Years } & \multirow{2}{*}{$\mathbf{2 0 2 0}$ by } \\
\cline { 2 - 6 } & $\mathbf{2 0 1 6}$ & $\mathbf{2 0 1 7}$ & $\mathbf{2 0 1 8}$ & $\mathbf{2 0 1 9}$ & $\mathbf{2 0 2 0}$ & $\mathbf{2 0 1 6 ,} \%$ \\
\hline $\begin{array}{l}\text { Total plantings, } \\
\text { thousand } \\
\text { hectares }\end{array}$ & 460.3 & 462.4 & 465.7 & 465.2 & 462.6 & 101 \\
\hline $\begin{array}{l}\text { Including at a } \\
\text { fertile age }\end{array}$ & 369.0 & 364.7 & 364.3 & 358.9 & 356.5 & 97 \\
\hline $\begin{array}{l}\text { Gross harvest, } \\
\text { thousand tons }\end{array}$ & 3,056 & 2,683 & 3,337 & 3,500 & 3,661 & 120 \\
\hline $\begin{array}{l}\text { Productivity, c } \\
\text { per 1 hectare of } \\
\text { harvested area }\end{array}$ & 88.4 & 77.9 & 96.1 & 101.4 & 106.6 & 121 \\
\hline $\begin{array}{l}\text { Total plantings, } \\
\text { thousand } \\
\text { hectares }\end{array}$ & 91.5 & 91.5 & 93.5 & 95.9 & 96.8 & 106 \\
\hline $\begin{array}{l}\text { Including at a } \\
\text { fertile age }\end{array}$ & 74.4 & 74.8 & 75.1 & 77.3 & 76.8 & 103 \\
\hline $\begin{array}{l}\text { Gross harvest, } \\
\text { thousand tons }\end{array}$ & 601 & 580 & 628 & 678 & 682 & 113 \\
\hline $\begin{array}{l}\text { Productivity, c } \\
\text { per 1 hectare of } \\
\text { harvested area }\end{array}$ & 86.6 & 84.9 & 91.9 & 95.9 & 92.3 & 107 \\
\hline
\end{tabular}

The main driver of the industry development was the measures of state support provided within the framework of the State Program for the Development of Agriculture and Regulation of Agricultural Products, Raw Materials and Food Markets, approved by Decree of the Government of the Russian Federation of July 14, 2012 No. 717 (hereinafter referred to as the State Program), including for laying and caring for perennial plantings.

Since the beginning of implementation of the State Program, agricultural producers for the period 2013-2020 have laid out 112.8 thousand hectares of perennial fruit and berry plantations, including nurseries, of which $66.1 \%$ (74.6 thousand hectares) are intensive fruit orchards.

By 2025, in the country, according to the target indicators of the State Program for 2021-2025, it is planned to establish perennial plantings on an area of at least 63.5 thousand hectares.

According to the results of 2020, 16.0 thousand hectares of new perennial fruit and berry plantations were laid, including nurseries, or $87.9 \%$ of the indicator of 2019 (18.2 thousand hectares) and 1.7 times higher than the foundation of 2013 (9.3 thousand hectares). The target indicator (11.4 thousand hectares) was exceeded by $40.4 \%$.

The forecast for laying in 2021, according to the target indicator of the State Program, is about 13.0 thousand hectares. According to management bodies of the agro-industrial complex of the constituent entities of the Russian Federation, in the spring period, gardeners have already laid out 6.2 thousand hectares, which is $47.7 \%$ of the target indicator. Laying will continue in the fall.

The systematic entry into fruiting of new planted orchards and berry plantations contributes to the annual increase in production of fruits and berries in agricultural organizations, peasant (farm) farms and individual entrepreneurs.

So, since 2013, the production of fruits and berries in the organized sector of the industry has increased 1.9 times from 678 thousand tons to $1,311.6$ thousand tons in 2020 . 
According to the governing bodies of the agro-industrial complex of the constituent entities of the Russian Federation, the forecast for production of fruits and berries in 2021 in agricultural enterprises, peasant farms and individual entrepreneurs will be about 1,510.0 thousand tons by 2025, this figure is planned to be increased to 2.2 million tons.

The leader in production of fruits and berries at the end of 2020 was the North Caucasian Federal District, which accounts for $42.3 \%$ of the total production in the organized sector of the country's industry. The Southern Federal District accounts for $38.1 \%$, Central $-15.1 \%$, Privolzhsky - $4.0 \%$. The North-West, Ural, Siberian and Far Eastern federal districts together account for about $0.5 \%$ of the total volume of commodity production in the country.

Among the subjects, the Kabardino-Balkarian Republic took the leading position - the gross harvest of fruits and berries in agricultural enterprises, peasant farms and individual entrepreneurs amounted to 445.9 thousand tons, the Krasnodar Territory moved to the second position - 306.4 thousand tons.

You can also highlight the Republic of Crimea (92.0 thousand tons), Voronezh region (74.6 thousand tons), Lipetsk region (54.6 thousand tons) [5].

At the same time, the sectoral potential in the country is represented by 36.4 thousand agricultural organizations, 174.8 thousand peasant farms and individual entrepreneurs, 18.2 million personal subsidiary and other individual farms of citizens. According to the letter from the Chairman of the Board of the Association of Planting Material Producers A.V. Orlova to the Chairman of the Committee on Agrarian and Food Policy of the Federal Assembly of the Federation Council of the Russian Federation dated November 07, 2019 No. $03 / 11$ in the structure of the total area of perennial plantations of fruit and berry crops (465.8 thousand hectares), the main share is the area of households of the population of 292 thousand hectares. The area of peasant (farm) households and individual entrepreneurs amounted to 31.8 thousand hectares or $6.9 \%$ of the total area of plantations, there is a tendency to increase the area of perennial plantations. So, in 2018 compared to 2017, they increased by 3.4 thousand hectares.

In this regard, we consider it necessary to develop the selection and assortment of fruit (berry) crops not only for industrial horticulture, but also to provide, among other things, categories of farms with small areas for the production of fruits and berries.

According to the Ministry of Agriculture of Russia [6], the fruit and berry market in the country is not stable and largely depends on weather conditions. Thus, production of fruits and berries in 2020 amounted to 4.4 million tons, which is $1.5 \%$ more than in 2019. As a result of the growth in the gross harvest of fruits and berries and imports, the total resources increased by 206.5 thousand tons, or $1.6 \%$.

Wherein, the consumption of fruits and berries per capita, according to the Ministry of Agriculture of Russia, in 2020 amounted to $62.7 \mathrm{~kg}$ at the recommended rate of $100 \mathrm{~kg}$ [1].

In December 2020, according to Rosstat, prices of agricultural producers increased compared to the same period in 2019 for pome fruits by $23.4 \%$, berries - by $15.2 \%$, grapes - by $9.4 \%$, stone fruits - by $7.4 \%$.

Consumer prices for fruits and citrus fruits in December 2020 compared to December 2019 increased by $12.94 \%$, including for apples - by $19.8 \%$, pears - by $11.5 \%$, oranges — by $23.5 \%$, lemons - by $6.5 \%$, bananas — by $0.3 \%$, grapes - by $8.5 \%$ [6].

It shall be noted that the import of fruits possible for production in the territory of the Russian Federation is quite high and varies from year to year in the range from 1.5 million tons in 2016 to 1.9 million tons in 2020 (data from the Federal Customs Service of Russia). Compared to the value of 2019 , the increase in imports amounted to $8.1 \%$.

In general, fruits that can be produced in the territory of the Russian Federation were imported in the amount of 132.7 billion dollars. 
At the end of 2020, fruit exports from the Russian Federation amounted to slightly more than 22 thousand tons - compared to 2019 , they decreased by $7.9 \%$ in the amount of USD 0.7 billion.

As for production of planting material, according to the data of the management bodies of the agro-industrial complex of the constituent entities of the Russian Federation, at the end of 2020, 30.2 million pieces of seedlings were produced (excluding strawberries and rootstocks). The entire volume of seedlings falls on establishment of industrial plantings and sale to the population.

The main volume of production falls on seedlings of seed crops -21.2 million pieces, seedlings of berry bush crops account for 5.4 million pieces, stone fruits -2.6 million pieces, and nut crops -0.9 million pieces.

Production of garden strawberry seedlings in 2020 amounted to 19.7 million pieces.

Imports of planting material (except for grapes, citrus fruits, cuttings, off-shoots, seedlings of garden strawberries) at the end of 2020 amounted to 25.7 million pieces in the amount of 49.5 million dollars, which is $6.6 \%$ more than in 2019 (24.1 million pieces).

The total volume of imports (25.7 million pieces) includes planting material for fruit, berry shrubs, walnut crops for the establishment of industrial plantings, rootstocks of fruit crops for the establishment of nurseries, as well as seedlings for the private sector of the industry [5].

\section{Discussion}

Currently, production of planting material and introduction of innovative technologies in the areas of domestic horticulture is highly dependent on foreign manufacturers. Therefore, it becomes necessary to transfer the industry to a sustainable path of development, using biological and technological factors of production. Projects for laying gardens shall be based on developed domestic or adapted to local conditions foreign standard technologies for the cultivation of fruit crops. These technologies shall consider the genetic potential of the fruit plant (breed-variety-stock) and the ecological conditions of the corresponding zones of the region, as well as the quality of the land allocated for perennial plantings.

Ensuring sustainable development of domestic horticulture is impossible without changing the legislative, regulatory and legal framework, as well as the organizational and economic conditions of state regulation in the industry.

As a legislative and regulatory framework in the horticulture of the country, it is necessary:

- to speed up the procedure for the adoption of the Federal Law "On Amendments to the Federal Law "On Seed Production";

- to develop additional measures of state support to ensure the economic attractiveness of activities in the field of domestic nursery breeding, using mechanisms to protect the rights of investors who invest in Russian nursery breeding on the basis of public-private partnerships;

- to consider the possibility of amending the Code of Administrative Offenses of the Russian Federation in terms of toughening liability for violations of intellectual rights in the field of domestic nursery breeding;

- to make changes to the appendices of the State Program in terms of providing the opportunity for scientific institutions to create breeding and nursery centers, using the rights in relation to the property assigned to them (operational management and permanent (unlimited) use) for production of revitalized planting material of the categories "Original" and "Elite" and providing mother plants with basic nurseries;

- to amend the legislation of the Russian Federation, allowing state scientific institutions to participate in the programs of state support for development of the material and technical 
base, the establishment of perennial plantations, including collections of genetic resources and plant breeding;

- to develop a set of measures to improve the system of state variety testing and registration of varieties, providing for: optimization of the number of state variety plots and the number of variety experiments that are mandatory for laying in the registration region. Establishment of economically justified prices for conducting state tests of breeding achievements and the procedure for granting discounts or benefits for Russian breeding and nursery centers for these works. Exceptions for testing foreign varieties and hybrids at the expense of the federal budget. [7]

In addition, the Decree of the Government of the Russian Federation of March 31, 2017 No. 396 "On Amendments to the State Program for Development of Agriculture and Regulation of Agricultural Products, Raw Materials and Food Markets for 2013-2020" allows the creation of seed-breeding (nursery) centers in crop production on the basis of economic entities with "ownership and (or) lease of agricultural land". Subsidies for the purpose of co-financing are provided for "... the creation and (or) modernization of selection and seed production centers in crop production, owned by agricultural producers".

As follows from this regulation, budgetary scientific institutions, due to their status and attitude to property, do not have legal grounds to participate in state support programs for agricultural producers, and experimental production farms of scientific institutions, even as agricultural producers, also do not have the opportunity to participate in special development support programs for agriculture: namely, in creation of selection and seedgrowing (nursery) centers for the production of initial forms and basic planting material for production of seedlings of fruit, berry, nut crops and grapes of the highest quality categories by reproduction nurseries, in view of the fact that agricultural lands on which they carry out production activities and are assigned to the scientific institutions that created them on the basis of the right of permanent (unlimited) use.

To involve scientific institutions in implementation of the most important national economic tasks, it is necessary to take measures to eliminate legal obstacles to participation of scientific institutions in state development and support programs, as well as to make additions (changes) to the Land Code of the Russian Federation in terms of providing scientific organizations with priority (without participation in tenders) the right of targeted lease of agricultural land for use in research and development purposes, as well as the transfer of these lands to the sub-lease of the dependent economic companies created - pilot production farms or unitary enterprises transformed into economic societies, or the adoption of a Resolution of the Government of the Russian Federation, wherein to formulate the law enforcement the practice of targeted implementation of the provisions of the Federal Laws [8].

Such a sequence of regulatory and legal actions shall be immediately developed and used in production of domestic varieties in the horticultural sub-sector. Otherwise, dependence of Russian gardeners on supply of foreign varieties will only increase, which will negatively affect the food security of the country.

The next direction of sustainable development of the horticultural industry is its transfer to an intensive development path. Intensive garden is a complex agro-technical complex for guaranteed fruit production. Starting from the fourth year of operation, it shall annually yield at least 50-70 t/ha, while these results shall not depend on natural disasters. Below we provide a calculation of the payback period for establishment of a superintensive garden, according to technological maps of horticultural organizations of the Krasnodar Territory, kindly provided to us by Interbusiness LLC (St. Krasnodar).

For calculations, we took a super-intensive garden with an area of 30 hectares, consisting of 6 blocks of 5 hectares. Technical parameters of the project:

- fruit crops: apple tree $20 \%$ of summer-autumn varieties and $80 \%$ of winter varieties; 
yield potential of $50-80 \mathrm{t} / \mathrm{ha}$;

- seedling planting diagram: $3.5 \mathrm{~m}$ x $0.7 \mathrm{~m}$ (superintensive technology);

- number of seedlings per hectare: 4,101 pcs. (considering the insurance fund of $0.5 \%$ );

- the total number of seedlings - 123,030 pcs.;

- trellis installation diagram: $3.5 \mathrm{~m}$ x $8 \mathrm{~m}$, height of pillars of $4.5 \mathrm{~m}$;

- drip irrigation system;

- anti-hail system based on nets and appropriate accessories.

The payback period of the project when laying a superintensive garden with an area of 30 hectares is presented in Table 2.

Table 3. The list of production costs by years and the terms of their payback when laying a superintensive garden of 30 hectares (Source: compiled by the authors on the basis of technological maps of Interbusiness LLC, Krasnodar).

\begin{tabular}{|c|c|c|c|c|c|c|c|c|}
\hline \multirow{2}{*}{ № } & \multirow{2}{*}{ Names of costs } & \multicolumn{7}{|c|}{ Years } \\
\hline & & 2019 & 2020 & 2021 & 2022 & 2023 & 2024 & 2025 \\
\hline 1 & $\begin{array}{l}\text { Capital investments, } \\
\text { including in the system } \\
\text { of protection against } \\
\text { negative natural } \\
\text { phenomena, thousand } \\
\text { rubles }\end{array}$ & 101,740 & 2,115 & 2,396 & 2,519 & 2,687 & 2,400 & 1,500 \\
\hline 2 & $\begin{array}{l}\text { Operating costs, } \\
\text { thousand rubles }\end{array}$ & 4,450 & 6,250 & 7,450 & 8,050 & 8,650 & 9,250 & 9,250 \\
\hline 3 & $\begin{array}{l}\text { Total, thousand rubles } \\
\text { (item } 1+\text { item } 2 \text { ) }\end{array}$ & 106,190 & 8,365 & 9,846 & 10,569 & $\begin{array}{c}11,33 \\
7\end{array}$ & 11,650 & 10,750 \\
\hline 4 & $\begin{array}{l}\text { Accumulated costs over } \\
\text { the years, thousand } \\
\text { rubles (item } 3, \\
\text { cumulative) }\end{array}$ & 106,190 & 114,555 & 124,401 & $\begin{array}{c}134,97 \\
0\end{array}$ & $\begin{array}{c}146,3 \\
07\end{array}$ & 157,957 & 168,707 \\
\hline 5 & Productivity, t/ha & 0 & 10 & 20 & 30 & 40 & 50 & 50 \\
\hline 6 & Gross harvest, t/ha & 0 & 300 & 600 & 900 & 1,200 & 1,500 & 1,500 \\
\hline 7 & $\begin{array}{l}\text { Gross income (at a } \\
\text { wholesale price of } 50 \\
\text { rubles } / \mathrm{kg} \text { ), thousand } \\
\text { rubles }\end{array}$ & 0 & 15,000 & 30,000 & 45,000 & $\begin{array}{c}60,00 \\
0\end{array}$ & 75,000 & 75,000 \\
\hline 8 & $\begin{array}{l}\text { Cumulative income by } \\
\text { years, thousand rubles } \\
\text { (item 7, with } \\
\text { accumulation) }\end{array}$ & 0 & 15,000 & 45,000 & 90,000 & $\begin{array}{c}150,0 \\
00\end{array}$ & 225,000 & 300,000 \\
\hline 9 & $\begin{array}{l}\text { Project net income, } \\
\text { thousand rubles (item } 8 \\
\text { - item 4) }\end{array}$ & $\begin{array}{c}- \\
106,190\end{array}$ & $-99,555$ & $-79,401$ & 44,970 & $\begin{array}{c}+3,69 \\
3\end{array}$ & $+67,043$ & $\begin{array}{c}+131,29 \\
3\end{array}$ \\
\hline
\end{tabular}

From the data in Table 2, it follows that the excess of income over expenses occurs already in the fifth year of garden operation. The estimated annual profit, starting from 2025 , will be at least 131,293 thousand rubles with a minimum garden life of 15 years. At the same time, the expected net income from the project for nine years will amount to $1,181,637$ thousand rubles. 
The estimated net income can be significantly higher, since the yield in superintensive type gardens can reach 80 tons per hectare, or $60 \%$ higher than it is assumed in the calculations. The project provides for an average cost of a hail protection system of 764,313 rubles per 1 hectare of garden. This protection system from HELIOS (Italy) is able to protect gardens from the following natural disasters:

- hail of any size, which can damage or destroy from 30 to $100 \%$ of the fruit;

- protects from heavy rainfalls that damage tree inflorescences and destroy the fruits of berry crops;

- protects against hurricane and squally winds, which damage or destroy up to $30 \%$ of the fruits;

- protects against recurrent frosts during flowering and bud swelling (yield losses from 30 to $70 \%$ );

- protects fruits from sunburn. Potential crop losses annually range from 5 to $10 \%$.

When using protective nets around the perimeter of the neighborhoods, the hail protection system protects fruit trees and berry fields from invasion of insects and birds, which has a beneficial effect on the growth of fruit and berry production.

\section{Conclusion}

The horticulture industry in the Russian Federation shows stable growth dynamics. Wherein, consumption of fruits and berries per capita in the country, according to the Ministry of Agriculture of Russia in 2020, amounted to only $62.7 \mathrm{~kg}$ at the recommended rate of $100 \mathrm{~kg}$. To solve this problem, it is necessary to accelerate development of domestic nursery growing in the country on the basis of improving the legislative and regulatory framework, as well as the development of intensive technologies in horticulture, capable of providing a profit of at least 130 million rubles per hectare in the fifth year of garden operation.

Such an integrated approach will make it possible to transfer the domestic horticulture industry to the path of sustainable development.

\section{References}

1. The doctrine of food security of the Russian Federation, approved by the Decree of the President of the Russian Federation (2020)

2. S.I. Nechaev, N.V. Ishchenko, Agribusiness, 68, 2 (2021)

3. The Ministry of Agriculture of Crimea received a subsidy to protect fields from hail. Crimean Truth (2020)

4. Bulletin "Areas, gross harvest and yield of perennial plantations in the Russian Federation in 2020" (2020)

5. I.V. Lebedev, Letter to the Chairman of the Federation Council Committee on Agrarian and Food Policy and Environmental Management (2021)

6. Order of the Government of the Russian Federation № 1671-r, National report on the progress and results of the implementation in 2020 of the State program for the development of agriculture and regulation of markets for agricultural products, raw materials and food (2021)

7. S.B. Karunin, Attachment to the letter № 10.1-788, SK to the Federation Council Committee on Agri-Food Policy and Environmental Management (2019)

8. V.A. Bagirov, Letter to the Federation Council Committee on Agrarian and Food Policy and Environmental Management № 10.4-165 (2019) 